\title{
Formulasi Nuclear Polyhedrosis Virus (NPV) untuk Mengendalikan Ulat Grayak Padi (Mythimna separata Walker) pada Tanaman Padi
}

\author{
TRISNANINGSIH DAN ARIFIN KARTOHARDJONO
}

Balai Besar Penelitian Tanaman Padi

(diterima Oktober 2008, disetujui Juli 2009)

\begin{abstract}
Formulation of NPV to Control Army Worm (Mythimna separata Walker) on Rice. Several methods can be used to control pest infestation, especially by the use of biological agents that do not contaminate environment. Virus as a biological agent has already been used to control army worm on some plants. Some benefits can be obtained when biological agents are used to control insect infestation. The objectives of these studies were to obtain: 1) a method to produce $M s \mathrm{NPV}$ formulation from rice army worm; 2) an effective and efficient method to pack and store MsNPV formulation as biological agent of rice army worm and 3) an efficient application method of $M s \mathrm{NPV}$ formulation to control rice army worm. These studies were conducted at laboratory and green house in Bogor and rice field in Indramayu (Pantura) and Sukabumi, West Java during the planting season of 2005. The experiment consisted of several parts: 1) production of suspension and $M s \mathrm{NPV}$ formulation from the larvae of rice army worm, 2) packing and period storing of $M s \mathrm{NPV}$ formulation, 3) observe the effect of $M s \mathrm{NPV}$ formulation on rice army worm in the rice fileds. Results from these studies show that the number of larvae used will effect production of suspension and formulation of $M s N P V$. The number of larvae used would increase the production of suspension and the value of formulation will also increase. While method of packing, period of time and location of storing showed that time period of 1;2; and 3 months at different colour of plastic (blue and white) also location of storing refrigerator vs room temperature (cupboard and table) did not effect on mortality of larvae rice armyworm.
\end{abstract}

KEYWORDS: Rice, army worm, NPV formulation

\section{PENDAHULUAN}

Pertanaman padi di lapangan selalu diserang oleh berbagai jenis hama. Diantara hama potensial yang serangannya luas, mendadak, dan dapat menyebabkan tanaman menjadi puso adalah ulat grayak padi (UGP), Mythimna separata Walker (Lepidoptera: Noc- tuidae). Pada tahun 2002, serangan ulat grayak mencapai sekitar 12114 ha dan serangan terluas terjadi di Sulawesi Selatan (2448 ha) dan Jawa Barat (2335 ha) (Direktorat Bina Perlintan 2003). Di Cirebon pada tahun 2004 pertanaman padi seluas 506 ha terserang hama ini dengan kerapatan populasi 1-3 ekor larva $/ \mathrm{m}^{2}$ serta se- 
rangan seluas 140 ha dengan kerapatan populasi 2-30 ekor larva/m² (Setiatin 2004). Karena serangan yang ditimbulkan sangat luas maka perlu diupayakan cara penanggulangannya.

Beberapa cara dapat digunakan untuk menanggulangi serangan hama, antara lain menggunakan agen hayati (parasitoid, predator dan microbial agents atau patogen serangga). Beberapa patogen serangga (jamur, bakteri, virus dan nematoda) telah digunakan untuk mengendalikan ulat grayak pada tanaman kedelai, tembakau dan kapas. Pengamatan Spodoptera $L \mathrm{Nu}$ clear Polyhedrosis Virus (SlNPV) pada tanaman kedelai pada dosis $9 \times 10^{8}$ $\mathrm{PIBs} / \mathrm{m} 2$ yang diformulasikan dengan tepung laktosum untuk pengendalian ulat grayak, Spodoptera L menyebabkan tingkat kematian ulat grayak 7981\% (Arifin et al., 1999). Pada tembakau, efektifitas Helicovtera armigera Nuclear Polyhedrosis Virus ( $\mathrm{Ha}$ NPV) meningkat pada perlakuan $\mathrm{HaNPV}+$ ajuvan A (mortalitas larva 72,5-74,9\%) dibandingkan dengan $\mathrm{Ha}$ NPV tanpa ajuvan A (mortalitas larva 27,8-56,4\%) (Gothama et al. 1999). Penggunaan molases dapat meningkatkan persistensi $H a \mathrm{NPV}$ di lapang sehingga lebih cepat menurunkan populasi H. armigera (Indrayani 1996). Pada ulat grayak tanaman padi, Mythimna separata Nuclear Polyhedrosis Virus (MsNPV) pada konsentrasi $10^{5}$ dapat menyebabkan mortalitas $53 \%$ pada 3 hari setelah inokulasi (hsi) dan pada 9 hsi dapat mencapai 95\%. Tiga formulasi yaitu talk, gypsum dan kaolin menyebabkan mortalitas 59$82 \%$. Penggunaan formulasi talk menyebabkan mortalitas ulat grayak tertinggi. Konsentrasi formulasi talk yang efektif adalah 1, 2 dan $3 \mathrm{~g} / 1 \mathrm{me}-$ nyebabkan mortalitas larva 86-95\%. (Kartohardjono et al. 2005). Steinhause dan Thompson (1949) dalam Martignoni (1973) menguraikan cara memperbanyak virus sebelum diaplikasian ke lapangan yaitu dengan menggunakan larva terinfeksi yang dimurnikan. Beberepa NPV telah dibuat formulasinya untuk digunakan sebagai agens pengendali.

Beberapa keuntungan pengendalian hama dengan menggunakan agens hayati seperti yang dikemukakan oleh Steinhaus (1956) dalam Hall (1973) antara lain: 1) patogen serangga tidak mencemari lingkungan; 2) sebagian besar patogen tingkat spesifikasinya relatif tinggi sehingga cenderung melindungi serangga berguna; 3) beberapa patogen dapat bersifat sinergis; 4) relatif lebih murah dibandingkan insektisida sintetis dan beberapa patogen dapat diproduksi sendiri; 5) pengaruh mikrobial patogen terhadap resistensi inangnya lambat; dan 6) dosis yang dibutuhkan dalam pengendalian rendah.

Penelitian ini bertujuan untuk mendapatkan: 1) cara memperbanyak $M s$ NPV dari larva UGP; 2) cara pengemasan dan penyimpanan formulasi 
$M s \mathrm{NPV}$; dan 3) mendapatkan cara memproduksi formulasi $M s \mathrm{NPV}$.

\section{BAHAN DAN METODE}

Penelitian dilaksanakan di Laboratorium dan Rumah Kaca BB. Padi KP. Muara Bogor, serta di lapangan yang dilakukan di Indramayu dan Sukabumi, Jawa Barat pada MT 2005.

\section{Perbanyakan, Pembuatan Suspensi dan Formulasi $M s$ NPV}

\section{A. Perbanyakan MsNPV}

Perbanyakan dilakukan terhadap sejumlah larva UGP diletakkan di wadah plastik (ukuran sedang diameter $19,5 \mathrm{~cm}$ dan tinggi $9 \mathrm{~cm}$ ). Percobaan menggunakan Rancangan Acak Lengkap (RAL). Setiap wadah diberi alas kertas dan diisi daun padi sebagai makanan lalu diaplikasi dengan menggunakan hand sprayer, disemprot Ms NPV dosis 2 gram/1, kemudian diinokulasi 30, 50 dan 70 larva UGP instar 3-4 pada setiap wadah sebagai perlakuan. Ulangan dilakukan 5 kali. Setiap larva yang terinfeksi $M s \mathrm{NPV}$ di dalam wadah dikumpulkan (dipanen). Pengamatan meliputi jumlah larva serangga yang terinfeksi. Larva yang terinfeksi disimpan sampai jumlahnya cukup untuk dibuat suspensi. Data dianalisis dengan tingkat perbedaan menggunakan (DMRT) 5\%.

\section{B. Pembuatan Suspensi MsNPV}

Larva yang terinfeksi diberi air sebanyak 2,5 ml, lalu digerus atau dihaluskan dengan menggunakan mor- tar; larva yang telah digerus disaring dengan saringan halus (500 mesh) sampai menjadi suspensi. Percobaan menggunakan RAL dan diulang 5 kali. Pengamatan dilakukan terhadap hasil suspensi yang diperoleh. Data dianalisis dengan DMRT 5\%.

\section{Pembuatan Formulasi MsNPV}

Bahan pembuatan formulasi terdiri dari tetes tebu atau molase (5\%) dan talk (95\%). Suspensi yang digunakan adalah $1 / 3$ bagian dari komposisi jumlah tetes tebu dan talk tersebut. Ketiga bahan tersebut diaduk lalu dikering-anginkan selama 24 jam (bebas sinar matahari), dihaluskan, dan disaring dengan saringan ukuran sedang sampai terbentuk serbuk formulasi. Perbandingan bahan, periode pengadukan, periode pengeringan, periode penghalusan dan jenis saringan yang digunakan dari setiap perlakuan sama. Perlakuan adalah jumlah larva yang digunakan yaitu 30, 50 dan 70 ekor dengan 3 ulangan. Pengamatan dilakukan terhadap hasil serbuk formulasi yang diperoleh. Data dianalisis dengan tingkat perbedaan menggunakan DMRT 5\%.

\section{Pengemasan, Tempat, Waktu Penyimpanan Formulasi dan Uji Efektivitas terhadap UGP}

Uji kemasan menggunakan kantong plastik warna putih dan warna biru. Formulasi yang diuji dimasukkan ke dalam kantong plastik masing-masing sebanyak 20 gram, kemudian disimpan di almari es, lemari biasa dan meja 
(suhu ruangan). Selanjutnya waktu penyimpanan formulasi dilakukan dengan perlakuan waktu simpan 1 bulan, 2 bulan dan 3 bulan. Pelaksanaan pengujian pengemasan dan tempat penyimpanan serta waktu simpan dilakukan bersamaan. Pengujian dilakukan di rumah kaca, dengan menggunakan tanaman padi varietas Ciherang umur 1 bulan di pot plastik. Perlakuan yang diuji adalah 1) Plastik putih disimpan di lemari es; 2) Plastik putih disimpan di almari biasa; 3) Plastik putih disimpan di atas meja pada suhu ruangan; 4) Plastik biru disimpan di almari es; 5) Plastik biru disimpan di almari biasa; 6) Plastik biru putih disimpan di atas meja pada suhu ruangan. Pengujian ini menggunakan RAL. Pengujian dilakukan pada periode penyimpanan 1 bulan, setiap tanaman pot disemprot sesuai dengan perlakuan lalu diinokulasi dengan 15 ekor larva instar 3-4 selanjutnya ditutup dengan plastik milar dengan 3 kali ulangan. Pengujian pada periode penyimpanan 2 dan 3 bulan, karena larva tersedia dalam jumlah terbatas maka setiap tanaman pot disemprot sesuai dengan perlakuan lalu diinokulasi dengan 14 ekor larva instar 3-4 selanjutnya ditutup dengan plastik milar. Pengamatan dilakukan terhadap mortalitas larva pada 3, 6, dan 9 hari setelah aplikasi (hsa) sampai larva menjadi pupa. Data dianalisis dengan tingkat perbedaan menggunakan DMRT 5\%.

\section{Uji formulasi di lapangan}

Pengujian pengaruh formulasi $M s$ NPV di lapangan dilakukan pada pertanaman padi di Indramayu dan Sukabumi, Jawa Barat. Pada setiap lokasi luas areal pertanaman padi digunakan adalah $800 \mathrm{~m}^{2}$. Budidaya padi varietas Ciherang dilakukan dengan teknik budidaya sesuai kebiasan petani. Lokasi penelitian dipilih lokasi yang terserang ulat grayak. Percobaan menggunakan Rancangan Acak Kelompok (RAK) dengan perlakuan sebagai berikut 1) inokulasi secara alami + aplikasi formulasi talk; 2) inokulasi secara alami sebagai kontrol ; 3) inokulasi buatan dalam kurungan plastik + aplikasi formulasi talk; dan 4) inokulasi buatan dalam kurungan plastik sebagai kontrol. Pada petak perlakuan inokulasi secara alami, jumlah serangga yang inokulasi tergantung pada keadaan populasi pada tanaman padi. Pada inokulasi buatan, setiap petak ukur, ke dalamnya diinokulasikan larva ulat grayak L3-L4 sebanyak 15 ekor. Aplikasi dilakukan pada tanaman padi berumur 1 bulan. Luas setiap petak $200 \mathrm{~m}^{2}$, kedalamnya ditentukan unit sampel berukuran $1 \mathrm{~m}$ x $1 \mathrm{~m}$ dan diulang 5 kali. Pengamatan dilakukan pada setiap unit sampel dengan menghitung jumlah larva yang ditemukan, jumlah larva terserang $M s$ NPV pada 5 dan 10 hari setelah aplikasi (hsa), dan skor kerusakan tanaman. Data dianalisis dengan tingkat perbedaan menggunakan DMRT 5\%. 
HASIL DAN PEMBAHASAN

I. Perbanyakan, Pembuatan Suspensi dan Formulasi MsNPV

\section{A.Perbanyakan formulasi $\mathbf{M s N P V}$}

Perlakuan jumlah larva yang digunakan setelah diinokulasi dengan disemprot, sembilan hari kemudian gejala virus menjadi 26,6; 41 dan 60 ekor larva (Tabel 1). Tidak semua larva yang diinokulasikan terserang MsNPV. Angka tersebut berbeda nyata antar perlakuan dengan nilai faktor koreksi 13,5\%. Selanjutnya jumlah larva yang terinfeksi tersebut untuk pembuatan suspensi.

\section{B.Pembuatan Suspensi}

Masing-masing perlakuan digerus dengan menggunakan mortar, dengan jumlah perlakuan larva yang berbeda (Tabel 1). Hasil penggerusan yang telah disaring diperoleh suspensi Ms$N P V$ berturut-turut 7,9 ml; 10,2 dan 13,1 ml (Tabel 1). Semakin banyak larva yang digerus akan menghasilkan suspensi yang lebih banyak. Berdasarkan pengalaman pembuatan suspensi dari 242 ekor larva yang digerus diperoleh $70 \mathrm{ml}$ suspensi (Kartohardjono et. al. 2005).Suspensi yang terjadi dilanjutkan untuk pembuatan formulasi.

\section{Pembuatan Formulasi}

Pembuatan formulasi dari suspensi yang telah terjadi dilakukan dengan menambahkan bahan penyerta yaitu talk dan molase sesuai dengan perbandingan masing-masing. Jumlah formulasi dari ketiga jumlah larva yaitu
26 larva mendapatkan 22,63 gram; 41 larva mendapatkan 29,75 gram dan 60 larva mendapatkan 38,7 gram (Tabel 1). Walaupun semakin banyak suspensi yang digunakan akan semakin banyak pula jumlah formulasi yang diperoleh, namun hasil analisis statistik antar perlakuan tidak berbeda nyata. Data tersebut tidak berbeda nyata dengan pembuatan suspensi dan formulasi yang telah dilakukan yaitu dari 242 ekor larva diperoleh $70 \mathrm{ml}$ suspensi selanjutnya diperoleh 208 gram formulasi talk $M s \mathrm{NPV}$ (Kartohardjono et al. 2005).

\section{Pengepakan, Tempat \\ Penyimpanan Formulasi dan Waktu Simpan Formulasi NPV serta Uji terhadap Ulat Grayak Padi di Laboratorium}

Pada pengujian periode penyimpanan 1 bulan, menunjukkan bahwa mortalitas larva telah tampak pada 3 hsa. Mortalitas meningkat pada 6 hsa dan 9 hsa (Tabel 2). Pada pengamatan 9 hsa menunjukkan bahwa perlakuan menggunakan plastik warna putih yang disimpan di lemari es, lemari biasa dan meja tidak berbeda nyata dengan kisaran 69-82,3 \% (Tabel 2). Sedang perlakuan menggunakan plastik biru yang disimpan di lemari es, lemari biasa dan meja juga tidak berbeda nyata tapi kisarannya antara 82,3-93,3 $\%$ (Tabel 2). Perbedaan yang nyata terjadi antara perlakuan dengan kontrol (tidak diaplikasi) dengan nilai c.v. $32 \%$. 
Tabel 1. Jumlah larva yang digunakan dan suspensi serta formulasi yang terjadi

\begin{tabular}{cccc}
\hline Perlakuan & $\begin{array}{c}\text { Jumlah Larva } \\
\text { terserang virus }\end{array}$ & Jumlah Suspensi (ml) & Jumlah Formulasi (gr) \\
\hline 30 larva & $26,6 \mathrm{a}$ & $7,9 \mathrm{a}$ & $22,6 \mathrm{a}$ \\
50 larva & $41,0 \mathrm{~b}$ & $10,2 \mathrm{a}$ & $29,8 \mathrm{a}$ \\
70 larva & $60,0 \mathrm{c}$ & $13,1 \mathrm{a}$ & $38,7 \mathrm{a}$ \\
\hline c.v. $(\%)$ & 13,5 & 55,0 & 55,7 \\
\hline Ket. : angka selajur yang diikuti oleh huruf yang sama tidak berbeda & nyata pada taraf 5\% DMRT
\end{tabular}

Tabel 2. Pengaruh waktu 1 bulan dan pengemasan serta tempat simpan $M s$ NPV terhadap mortalitas ulat grayak padi di Laboratorium. MT 2005

\begin{tabular}{lccc}
\hline \hline Perlakuan & \multicolumn{3}{c}{ mortalitas ulat grayak (\%) } \\
\cline { 2 - 4 } & $3 \mathrm{hsa}$ & $6 \mathrm{hsa}$ & $9 \mathrm{hsa}$ \\
\hline 1. Putih lemari es & $13,4 \mathrm{ab}$ & $55,7 \mathrm{ab}$ & $82,3 \mathrm{~b}$ \\
2. Putih lemari biasa & $22,2 \mathrm{~b}$ & $57,7 \mathrm{ab}$ & $77,7 \mathrm{~b}$ \\
3. Putih meja & $15,5 \mathrm{ab}$ & $51,0 \mathrm{ab}$ & $69 \mathrm{ab}$ \\
4. Biru lemari es & $11,1 \mathrm{ab}$ & $64,3 \mathrm{~b}$ & $82,3 \mathrm{~b}$ \\
5. Biru lemari biasa & $24,4 \mathrm{~b}$ & $75,7 \mathrm{~b}$ & $93,3 \mathrm{~b}$ \\
6. Biru meja & $11,1 \mathrm{ab}$ & $77,7 \mathrm{~b}$ & $93,3 \mathrm{~b}$ \\
7. Kontrol (tidak diaplikasi) & $4,6 \mathrm{a}$ & $22,3 \mathrm{a}$ & $31,1 \mathrm{a}$ \\
\hline c.v (\%) & 32,6 & 25,4 & 32,7 \\
\hline
\end{tabular}

Ket : Angka selajur diikuti oleh huruf yang sama tidak berbeda nyata berdasarkan DMRT 5\%

Pada pengujian periode penyimpanan 2 bulan, menunjukkan bahwa mortalitas larva masih rendah pada 3 hari setelah aplikasi (hsa). Pengaruh aplikasi formulasi talk $M s \mathrm{NPV}$ baru tampak pada 6 hsa, mortalitas larva antar perlakuan berkisar $20-36,6 \%$ dan berbeda nyata lebih besar dengan kontrol (tidak adiaplikasi) (6,7\%) (Tabel 3). Pada pengamatan 9 hsa menunjukkan bahwa perlakuan menggunakan plastik warna putih yang disimpan di lemari es, lemari biasa dan meja tidak berbeda nyata dengan kisaran antara 43,4-50\% (Tabel 3). Sedang perlakuan menggunakan plastik warna biru yang disimpan di lemari es, lemari biasa dan meja juga tidak berbeda nyata tapi kisarannya antara 36,7-43,4\% (Tabel 3).

Periode penyimpanan 3 bulan, mortalitas larva belum tampak pada 3 hsa. Mortalitas baru tampak pada 6 hsa, diantara perlakuan $(35,7-60,7 \%)$ berbeda nyata lebih besar dari pada kontrol (10,7\%). Pada 9 has menunjukkan bahwa perlakuan menggunakan plastik warna putih yang disimpan di lemari es, lemari biasa dan meja tidak berbeda nyata dengan kisaran 64,3-75 $\%$ (Tabel 4). Sedang perlakuan menggunakan plastik biru yang disimpan di lemari es, lemari biasa dan meja juga tidak berbeda nyata tapi kisarannya antara 67, 9-85, $5 \%$ (Tabel 4) 


\section{Uji Formulasi MsNPV di Lapangan}

Pengujian yang dilakukan di Cikembar (Sukabumi) pada pengamatan 5 hsa mortalitas pada perlakuan alami $20 \%$, sedang perlakuan semi alami 23\%-27\% dan tidak berbeda nyata. Pada 10 hsa perlakuan semi alami mortalitas pada kontrol $88 \%$ dan perlakuan talk $98 \%$, dan berbeda nyata yaitu kedua perlakuan tersebut.

Hasil pengujian di Sukra (Indramayu) pada pengamatan 5 hsa mortalitas pada perlakuan semi alami mortalitas pada kontrol $12 \%$ dan perlakuan talk 38,7\% dan berbeda nyata. Pada 10 hsa perlakuan semi alami mortalitas kontrol $48 \%$ dan perlakuan talk $77,4 \%$ dan berbeda nyata (Tabel 5).

Kelemahan penggunaan NPV dapat diperbaiki dengan menggunakan teknik formulasi, dengan penambahan ajuvan dan atau sinergis seperti bahan pelindung terhadaap radiasi matahari, perata, perekat, antifeden (penghenti nafsu makan) dan entomopatogen lain yang kompatibel (Farrar \& Ridway 1997 dalam Gothama et al. 1999).

Perbaikan MsNPV yang telah dilakukan, jumlah larva yang digunakan, semakin banyak larva yang digunakan maka akan semakin banyak larva yang terinfeksi MsNPV. Berdasarkan Tanada dan Kaya (1993 dalam Arifin et al. 1999), NPV yang tidak diformulasikan kurang efektif jika dibandingkan dengan yang diformulasikan, hal ini disebabkan oleh berkurangnya viabilitas, stabilitas dan patogenisitas NPV yang tidak diformulasikan karena mendapat paparan sinar matahari. Patogen serangga (virus) peka terhadap sinar ultraviolet sehingga diupayakan menggunakan kemasan kantong plastik berwarna putih dan biru. Patogen serangga (virus) juga peka terhadap suhu udara dan kelembaban, sehingga upaya penyimpanan dilakukan di lemari biasa dan di meja pada suhu ruangan.

Tabel 3. Pengaruh waktu penyimpanan 2 bulan dan pengemasan serta tempat penyimpanan $M s \mathrm{NPV}$ terhadap ulat grayak padi di Laboratorium. MT 2005

\begin{tabular}{lccc}
\hline \hline Perlakuan & \multicolumn{3}{c}{ mortalitas ulat grayak (\%) } \\
\cline { 2 - 4 } & $3 \mathrm{hsa}$ & $6 \mathrm{hsa}$ & $9 \mathrm{hsa}$ \\
\hline 1.Putih lemari es & $13,4 \mathrm{a}$ & $36,7 \mathrm{~b}$ & $43,4 \mathrm{~b}$ \\
2.Putih lemari biasa & $0 \mathrm{a}$ & $23,3 \mathrm{ab}$ & $43,4 \mathrm{~b}$ \\
3.Putih meja & $6,7 \mathrm{a}$ & $26,7 \mathrm{~b}$ & $50,0 \mathrm{~b}$ \\
4.Biru lemari es & $3,4 \mathrm{a}$ & $20,0 \mathrm{ab}$ & $36,7 \mathrm{~b}$ \\
5.Biru lemari biasa & $10,0 \mathrm{a}$ & $23,3 \mathrm{ab}$ & $40,0 \mathrm{~b}$ \\
6.Biru meja & $3,4 \mathrm{a}$ & $33,3 \mathrm{~b}$ & $43,4 \mathrm{~b}$ \\
7.Kontrol & $3,4 \mathrm{a}$ & $6,7 \mathrm{a}$ & $16,7 \mathrm{a}$ \\
\hline c.v (\%) & 70,68 & 18,53 & 9,81 \\
\hline
\end{tabular}

Ket. : Angka selajur diikuti oleh huruf yang sama tidak berbeda nyata dengan DMRT 5\% 
Tabel 4. Pengaruh waktu penyimpanan 3 bulan dan pengemasan serta tempat simpan $M s$ NPV terhadap ulat grayak padi di Laboratorium. MT 2005

\begin{tabular}{lccc}
\hline Perlakuan & \multicolumn{3}{c}{ mortalitas ulat grayak (\%) } \\
\cline { 2 - 4 } & $3 \mathrm{hsa}$ & $6 \mathrm{hsa}$ & $9 \mathrm{hsa}$ \\
\hline 1.Putih lemari es & $0 \mathrm{a}$ & $35,7 \mathrm{ab}$ & $64,3 \mathrm{~b}$ \\
2.Putih lemari biasa & $3,5 \mathrm{a}$ & $50,0 \mathrm{~b}$ & $64,3 \mathrm{~b}$ \\
3.Putih meja & $3,5 \mathrm{a}$ & $60,7 \mathrm{~b}$ & $75,0 \mathrm{~b}$ \\
4.Biru lemari es & $7,1 \mathrm{a}$ & $53,5 \mathrm{~b}$ & $67,9 \mathrm{~b}$ \\
5.Biru lemari biasa & $3,5 \mathrm{a}$ & $57,2 \mathrm{~b}$ & $85,5 \mathrm{~b}$ \\
6.Biru meja & $7,1 \mathrm{a}$ & $50,0 \mathrm{~b}$ & $67,9 \mathrm{~b}$ \\
7.Kontrol & $0 \mathrm{a}$ & $10,7 \mathrm{a}$ & $14,3 \mathrm{a}$ \\
\hline c.v (\%) & 96,48 & 19,75 & 15,16 \\
\hline
\end{tabular}

Ket. : Angka selajur diikuti oleh huruf yang sama tidak berbeda nyata dengan DMRT 5\%

Tabel 5. Mortalitas larva ulat grayak padi karena talk MsNPV di Cikembar, Sukabumi dan Sukra, Indramayu. MT 2005

\begin{tabular}{lcccc}
\hline \hline Perlakuan & \multicolumn{4}{c}{ mortalitas ulat grayak (\%) } \\
\cline { 2 - 5 } & \multicolumn{2}{c}{ Cikembar, Sukabumi } & \multicolumn{2}{c}{ Sukra, Indramayu } \\
\cline { 2 - 5 } & $5 \mathrm{hsa}$ & $10 \mathrm{hsa}$ & $5 \mathrm{hsa}$ & $10 \mathrm{hsa}$ \\
\hline Alami+talk & $20 \mathrm{a}$ & $0 \mathrm{a}$ & $0 \mathrm{a}$ & $0 \mathrm{a}$ \\
Alami+kontrol & $0 \mathrm{a}$ & $0 \mathrm{a}$ & $0 \mathrm{a}$ & $0 \mathrm{a}$ \\
Inok+talk & $27 \mathrm{a}$ & $98 \mathrm{c}$ & $38,7 \mathrm{c}$ & $77,4 \mathrm{c}$ \\
Inok+kontrol & $23 \mathrm{a}$ & $88 \mathrm{~b}$ & $12 \mathrm{~b}$ & $48 \mathrm{~b}$ \\
\hline c.v. (\%) & 90,79 & 10,4 & 53,73 & 16,22 \\
\hline
\end{tabular}

Ket.: - Data dianalisis dengan ditransformasi ArcsinVX +0.5

- Angka selajur yang diikuti oleh huruf yang sama tidak berbeda nyata dengan DMRT 5\%

Dosis dan bahan formulasi NPV yang efektif dan efisien ditentukan berdasarkan kriteria: a) tingkat kematian ulat minimal yang mencapai $70 \%$; b) waktu yang dibutuhkan untuk mencapai tingkat kematian $70 \%$ relatif singkat; c) tingkat kerusakan daun yang diakibatkan oleh ulat yang bertahan hidup relatif rendah; d) dosis yang diperlukan cukup ekonomis; e) bahan formulasi yang digunakan mudah diaplikasikan (Arifin et al. 1999). Waktu penyimpanan 3 bulan mortalitas larva berkisar antara 64,3-85,5\%. Pe- ngemasan menggunakan kantong plastik berwarna putih dan biru menunjukkan tidak berbeda nyata. Penyimpanan di lemari es, lemari biasa dan di meja pada suhu ruangan mortalitas larva tidak berbeda nyata berturut-turut $62,8 \% ; 67,4 \%$ dan $66,5 \%$.

Pengaruh formulasi $M s$ NPV terhadap larva ulat grayak di lapangan, tampak pada hasil inokulasi semi alami. Pengujian di Cikembar, Sukabumi dan Sukra, Indramayu perlakuan talk persentase mortalitas larva UGP lebih besar dan berbeda nyata di- 
banding dengan kontrol. Hal tersebut juga terjadi pada pengujian, tahun 2004 yang dilakukan di tiga lokasi berbeda (Kartohardjono et al. 2005).

\section{KESIMPULAN}

Perbanyakan suspensi dan formulasi $M s \mathrm{NPV}$, untuk mendapatkan jumlah suspensi dan formulasi dalam jumlah yang banyak diperlukan jumlah larva yang banyak pula. Pengemasan dengan plastik warna putih dan biru yang disimpan selama 1;2 dan 3 bulan yang disimpan dalam almari es , almari biasa dan meja pada suhu ruangan tidak berpengaruh terhadap mortalitas UGP. Formulasi talk $M s$ NPV pada pe-ngujian di lapang efektif terhadap larva UGP.

\section{DAFTAR PUSTAKA}

Arifin M, Villayanti I, Alwi A. 1999. Keefektifan SINPV pada berbagai bahan formulasi terhadap ulat grayak, Spodoptera litura (F.) pada kedelai. Seminar Nasional PEI Bogor 16 Feb.1999 $: 149-158$.

Direktorat Bina Perlindungan Tanaman. 2003. Evaluasi Serangan Organisme Pengganggu Tanaman Padi Selama 5 Tahun (19892002). Dir. Jen. Tan. Pangan dan Horti. Jkt.
Gothama AAA, Kumala I, Winarno D, Indrayani IGAA. 1999. Peningkatan efektifitas Helicoverpa armigera (Lepidoptera: Noctuidae) Nuclear Polyhedrosis Virus dengan beberapa Ajuva. Seminar Nasional PEI Bogor 16 Feb.:189 $-196$.

Hall IM. 1973. Use of Micro-organism in Biological Control. In Debach (ed) Biological control of insect pests and weeds .: Chapman and Hall Ltd. London. Pp. 610 - 628 .

Indrayani IGAA. 1996. Perkembangan pemanfaatan NPV dalam pengendalian serangga hama utama pada kapas. Panduan dan kumpulan intisari. Seminar Nasional Pengendalian Hayati Yogyakarta 25 - 26 Nop.1996: 9.

Kartohardjono A,Sukmana C, Rosadi E, Umar. 2004. Tehnik formulasi dan efikasi Nuclear Polyhedrosis Virus terhadap ulat gratyak, Mythimna separata pada tanaman padi. Laporan akhir T.A. 2004. BALITPA. $22 \mathrm{~h}$.

Martignoni ME. 1973. Mass Production of insect pathogens : $579-$ 609. In Debach (ed) Biological control of insect pests and weeds. Chapman and Hall Ltd.

Setiatin T. 2004. Data surveilance OPT padi sawah di Kabupaten Cirebon. (Mimeo). 